\title{
Cone Contacts, Mosaics, and Territories of Bipolar Cells in the Mouse Retina
}

\author{
Heinz Wässle, ${ }^{1}$ Christian Puller, ${ }^{1}$ Frank Müller, ${ }^{2}$ and Silke Haverkamp ${ }^{1}$ \\ ${ }^{1}$ Department of Neuroanatomy, Max Planck Institute for Brain Research, D-60528 Frankfurt, Germany, and 2Institute for Neuroscience and Biophysics 1, \\ Forschungszentrum Jülich, D-52425 Jülich, Germany
}

We report a quantitative analysis of the different bipolar cell types of the mouse retina. They were identified in wild-type mice by specific antibodies or in transgenic mouse lines by specific expression of green fluorescent protein or Clomeleon. The bipolar cell densities, their cone contacts, their dendritic coverage, and their axonal tiling were measured in retinal whole mounts. The results show that each and all cones are contacted by at least one member of any given type of bipolar cell (not considering genuine blue cones). Consequently, each cone feeds its light signals into a minimum of 10 different bipolar cells. Parallel processing of an image projected onto the retina, therefore, starts at the first synapse of the retina, the cone pedicle. The quantitative analysis suggests that our proposed catalog of 11 cone bipolar cells and one rod bipolar cell is complete, and all major bipolar cell types of the mouse retina appear to have been discovered.

Key words: bipolar cells; convergence; divergence; cone contacts; coverage; tiling

\section{Introduction}

Bipolar cells transfer the light signals from the photoreceptors (cones and rods) to amacrine and ganglion cells. There are at least nine morphological types of cone bipolar (CB) and one type of rod bipolar (RB) cells in the mammalian retina. They differ in their dendritic branching pattern, the number of cones contacted, and the shape and stratification level of their axons in the inner plexiform layer (IPL) (Masland, 2001; Wässle, 2004, 2008).

Functionally, bipolar cells can be subdivided, according to their light responses, into ON and OFF bipolar cells (Kolb and Nelson, 1995; Euler et al., 1996; Hartveit, 1997; DeVries, 2000). This functional dichotomy is the result of the expression of different glutamate receptors (GluRs) at the synapses between photoreceptors and bipolar cell dendrites (Nomura et al., 1994; Brandstätter et al., 1997; DeVries, 2000; Hack et al., 1999, 2001; Haverkamp et al., 2001).

The morphological classification of bipolar cells has been made more objective and more quantitative by immunocytochemical markers that selectively label specific cell types. Protein kinase $\mathrm{C}(\mathrm{PKC} \alpha)$ has been found to be expressed by RB cells (Negishi et al., 1988; Greferath et al., 1990). During recent years, several immunocytochemical markers of CB cells have been identified, such as antibodies against calcium binding proteins ( $\mathrm{CaB} 5$, calbindin, recoverin, or calsenilin), transmitter receptors (neurokinin receptors $\mathrm{NK}_{1} \mathrm{R}$ and $\mathrm{NK}_{3} \mathrm{R}$ ), membrane channels (hyperpolarization-activated cyclic-nucleotide gated channels

Received Sept. 17, 2008; revised Nov. 13, 2008; accepted Nov. 26, 2008.

This work was supported by a grant from the Deutsche Forschungsgemeinschaft (FOR 701, PE 38/16-1). We are grateful to Dr. Hannah Monyer and Dr. Dragos Inta for providing the 5- $\mathrm{HT}_{3} \mathrm{R}$-EGFP mouse line. We thank B. Marshallsay for technical assistance and I. Odenthal for typing this manuscript.

Correspondence should be addressed to Heinz Wässle, Max-Planck-Institut für Hirnforschung, Deutschordenstrasse 46, D-60528 Frankfurt/Main, Germany. E-mail: waessle@mpih-frankfurt.mpg.de.

D0I:10.1523/JNEUROSCI.4442-08.2009

Copyright $\odot 2009$ Society for Neuroscience $\quad$ 0270-6474/09/290106-12\$15.00/0
HCN1-HCN4), cell adhesion molecules (cluster of differentiation CD15), or synaptic vesicle proteins (synaptotagmin).

More recently, expression of green fluorescent protein (GFP) under the control of specific promoters has been observed in specific types of bipolar cells of the mouse retina. All ON bipolar cells were labeled with GFP driven by the mGluR6 (metabotropic glutamate receptor 6) promoter (Dhingra et al., 2008). Type 7 cone bipolar cells expressed GFP under the control of the gustducin promoter (Gus-GFP) (Huang et al., 2003). Blue cone bipolar cells expressed Clomeleon (Clm) driven by the thy-1 promoter (Haverkamp et al., 2005; Berglund et al., 2006).

It was the aim of the present study to define and apply selective markers for all nine morphological types of cone bipolar cells of the mouse retina (Ghosh et al., 2004). The markers were antibodies and/or specific expression of fluorescent proteins in transgenic mouse lines. With the exception of Type 8 cells, we were able to define such markers for all bipolar cells and study, in retinal whole mounts, their cone contacts, densities, and axonal patterns. The dendritic overlap (coverage) of neighboring bipolar cells of the same type is small (coverage smaller than 2). However, a given cone, not considering true/genuine blue cones, is contacted by at least one bipolar cell of any given type. The sum of the bipolar cell densities measured here for the individual types is in close agreement with the total bipolar cell density reported by Jeon et al. (1998). The set of bipolar cells described in the present study appears, therefore, complete, meaning that no major class of mouse bipolar cells seems to be missing.

\section{Materials and Methods}

Wild-type mice (C57BL/6J) and the following transgenic mouse lines were used. Two mouse lines (genetic background C57BL/6J), Clm1 and Clm12, expressed Clomeleon, a genetically encoded ratiometric fluorescent indicator for $\left[\mathrm{Cl}^{-}\right]$under the thy-1 promoter (Feng et al., 2000; Berglund et al., 2006). One mouse line (genetic background C57BL/6J) expressed GFP under the gustducin promoter (Wong et al., 1999; Huang 


\begin{tabular}{|l|c|c|c|c|c|c|c|c|c|c|}
\hline & & OFF-Bipolar cells & \\
\hline
\end{tabular}

Figure 1. Bipolar cell types of the mouse retina (Ghosh et al., 2004) and the markers and transgenic mouse lines used in the present study. Csen, Calsenilin. For details, see Materials and Methods.

et al., 2003). One mouse line (genetic background C57BL/6NCrl) expressed enhanced GFP (EGFP) under the control of the serotonin 3 receptor $\left(5-\mathrm{HT}_{3} \mathrm{R}\right)$ (Haverkamp et al., 2009). The mice were deeply anesthetized with isoflurane and killed by cervical dislocation. All procedures were approved by the local animal care committee and were in accordance with the law of animal experimentation issued by the German Government (Tierschutzgesetz). The eyes were removed and dissected, and the posterior eye cup containing the retina was immediately immersed in $4 \%$ (w/v) paraformaldehyde in $0.1 \mathrm{~m}$ phosphate buffer, $\mathrm{pH} 7.4$, for 15-30 min. After fixation, the retina was dissected from the eyecup. For frozen sections, it was cryoprotected in graded sucrose solutions (10, 20 , and $30 \% \mathrm{w} / \mathrm{v}$, respectively), and cryostat sections were cut at $14 \mu \mathrm{m}$, mounted, and stored at $-20^{\circ} \mathrm{C}$. For retinal whole mounts, the tissue was cryoprotected and frozen and thawed several times. Whole mounts were processed free floating.

Antibodies. Clomeleon consists of Topaz, a variant of the yellow fluorescent protein and cyan fluorescent protein fused together. Hence, it is already visible without immunostaining because of its green/yellow fluorescence. However, by applying antibodies against GFP, the fluorescence signal was substantially increased: rabbit anti-GFP (1:2000; Invitrogen) and mouse anti-GFP (1:500; Millipore Bioscience Research Reagents). The same antibodies were also used for the amplification of GFP and EGFP signals. Cone pedicles were labeled with a guinea pig antiserum against glycogen phosphorylase (glypho) (1:1000) (PfeifferGuglielmi et al., 2003) (kind gift from B. Hamprecht and B. PfeifferGuglielmi, University of Tübingen, Tübingen, Germany) and with a goat antibody against GluR5C (1:100; Santa Cruz Biotechnology), which is expressed at the dendritic tips of OFF bipolar cells (Haverkamp et al., 2003). The layering within the inner plexiform layer was revealed by a mouse monoclonal antibody against calretinin (1:2000; Millipore Bioscience Research Reagents). Horizontal cells were labeled with a rabbit antibody against calbindin (CaBP, 1:2000; Swant). Cholinergic amacrine cells were immunostained with a goat antibody against choline acetyltransferase (ChAT) (1:2000; Millipore Bioscience Research Reagents).

We used the following immunocytochemical markers for mouse bipolar cells (Fig. 1): anti-NK 3 R (rabbit, polyclonal, 1:500; kind gift from A. Hirano, Geffen School of Medicine at University of Los Angeles, Los Angeles, CA) for Type 1/2 bipolar cells (Haverkamp et al., 2003; Ghosh et al., 2004; Pignatelli and Strettoi, 2004; Chang et al., 2006); anti-HCN4 (rabbit, polyclonal, 1:500; Alomone Labs) for Type 3a bipolar cells (Ma- taruga et al., 2007); anti-protein kinase A, regulatory subunit II $\beta$ (PKARII $\beta$ ) (mouse, monoclonal, 1:3000; BD Biosciences) for Type 3b bipolar cells (Mataruga et al., 2007); anticalsenilin (mouse, monoclonal, 1:2000; kind gift from W. Wasco, Harvard Medical School, Charlestown, MA) for Type 4 bipolar cells (Haverkamp et al., 2008); and antisynaptotagmin II (Syt2 or ZNP-1; mouse, monoclonal, 1:200; Zebrafish International Resource Center, University of Oregon, Eugene, OR) for Type 2 (Fox and Sanes, 2007) and Type 6 bipolar cells (described herein).

Antibodies were diluted in PBS, pH 7.4, containing $0.5-1 \%$ Triton $\mathrm{X}-100$ and $0.05 \%$ sodium azide with either $3 \%$ normal donkey serum or $5 \%$ Chemiblocker (Millipore Bioscience Research Reagents) or without a blocking substance in the case of $\mathrm{NK}_{3} \mathrm{R}$ staining. Immunocytochemical labeling was performed using the indirect fluorescence method. Cryostat sections were incubated overnight in the primary antibodies, followed by incubation $(1 \mathrm{~h})$ in the secondary antibodies, which were conjugated to Alexa TM 488 (green fluorescence; Invitrogen), cyanine 3 (red fluorescence; Dianova), or cyanine 5 (dark red fluorescence). In double-labeling experiments, sections were incubated in a mixture of primary antibodies, followed by a mixture of secondary antibodies. Whole mounts were incubated for $2 \mathrm{~d}$ in the primary and for $2 \mathrm{~h}$ in the secondary antibody solution. The Alexa 594-conjugated lectin peanut agglutinin (PNA) (Invitrogen) was used at a 1:200 concentration, and whole mounts were incubated for $2 \mathrm{~h}$.

Light microscopy. Fluorescent specimens were viewed with a Zeiss Axioplan 2 microscope with a fluorescent filter set that was wedge corrected, i.e., shifting from one filter to the other did not introduce displacements. Black-and-white images were taken by using a cooled CCD camera (AxioCam Mrm; Zeiss). By using the Zeiss AxioVision 4.2 software, images taken with the different fluorescence filters were pseudocolored and superimposed. The microscope was equipped with the Zeiss Apotome oscillating grating in the epifluorescence beam, which resulted in a significant reduction of out-of-focus stray light. Images were taken with a Plan-Neofluar $63 \times / 1.4$ oil-immersion objective as stacks of up to 30 optical sections taken from the cone pedicles to the bipolar cell axon terminals. The cone contacts, dendritic trees, and axon terminals were analyzed by looking through the individual sections. Density measurements were made by collapsing selected parts of the stacks into a single plane. Confocal micrographs were taken using a Zeiss LSM Pascal fluorescence microscope equipped with an argon and a helium/neon laser. High-resolution scanning was performed with a Plan-Apochromate $63 \times / 1.4$ objective. Usually, a stack of 12 sections was taken from the inner nuclear layer (INL) to the outer plexiform layer (OPL) ( $z$-axis step size, $0.6 \mu \mathrm{m}$ ). Another stack was taken afterward from the INL to the axon terminals.

The densities of cone pedicles and bipolar cells were always measured in the same retinal fields that were double labeled for a cone pedicle marker (PNA, glypho, or GluR5) and a type-selective bipolar cell marker. Usually, $\sim 10$ fields ( $141 \mu \mathrm{m}$ long and $106 \mu \mathrm{m}$ wide) were analyzed. They were sampled from different eccentricities and from two or three different retinal whole mounts. For each field, the cone density, the bipolar cell density, and the ratio of cone density to bipolar cell density were measured. The arithmetic means of the measurements are listed in Table 1. The numbers of cones contacted by an individual bipolar cell were measured from well isolated individual bipolar cells and are shown by frequency histograms.

The brightness and the contrast of the final images were adjusted using Photoshop 5.5 (Adobe Systems).

Comparison of mouse strains. Because it is known that various mouse 
Table 1. Comparison of the cone and bipolar cell densities

\begin{tabular}{|c|c|c|c|c|c|}
\hline Type & $n$ & Bipolar cell density per $\mathrm{mm}^{2}$ & Cone density per $\mathrm{mm}^{2}$ & Ratio cone density bipolar density & Convergence \\
\hline Type 1 & 10 & $2233 \pm 399$ & $11,840 \pm 1315$ & $5.4 \pm 0.9$ & 8 \\
\hline Type 2 & 11 & $3212 \pm 543$ & $11,806 \pm 1371$ & $3.8 \pm 0.7$ & 5.6 \\
\hline Type 3a & 16 & $1866 \pm 605$ & $10,941 \pm 2804$ & $6.1 \pm 0.9$ & 7.6 \\
\hline Type 3b & 11 & $3254 \pm 536$ & $12,824 \pm 2129$ & $4.0 \pm 0.4$ & 6.2 \\
\hline Type 4 & 12 & $3005 \pm 573$ & $13,836 \pm 1530$ & $4.6 \pm 0.7$ & 6.9 \\
\hline Type 5 & 10 & $5001 \pm 631$ & $12,687 \pm 1755$ & $2.6 \pm 0.5$ & $>6$ \\
\hline Type 6 & 8 & $3379 \pm 372$ & $12,916 \pm 1006$ & $3.9 \pm 0.5$ & $?$ \\
\hline Type 7 & 9 & $2256 \pm 221$ & $14,833 \pm 2602$ & $6.6 \pm 1.2$ & 8.4 \\
\hline Type 9 (BB) & 6 & $616 \pm 135$ & $13,167 \pm 2187$ & $21.7 \pm 2.4$ & \\
\hline \multirow[t]{2}{*}{$\mathrm{RB}$} & 10 & $15,153 \pm 2324$ & $13,827 \pm 2033$ & $0.9 \pm 0.1$ & \\
\hline & & Sum 39,975 & Mean 12,867 \pm 1142 & & \\
\hline Types 1 and $2\left(\mathrm{NK}_{3} \mathrm{R}\right)$ & 12 & $4556 \pm 1491$ & $11,185 \pm 3186$ & $2.5 \pm 0.4$ & $5-8$ \\
\hline Types 3a and 3b & 16,11 & 5120 & 11,882 & 2.3 & $6-8$ \\
\hline Type 5 & 10 & $5001 \pm 631$ & $12,687 \pm 1755$ & $2.6 \pm 0.5$ & $>6$ \\
\hline
\end{tabular}

The top part of the table lists the individual bipolar cell types, the number of fields analyzed ( $n$ ), the bipolar cell density, the cone density, the ratio of cone density to bipolar cell density, and the convergence (number of cones contacted by individual bipolar cells). The data referring to Type 9 [blue cone bipolar (BB)] cells were taken from the study of Haverkamp et al. (2005). The data referring to RB cells were measured in PKC $\alpha$ - stained retinal whole mounts. The bottom part of the table lists the results if two bipolar cell types are labeled ( $\mathrm{NK}_{3} \mathrm{R}$, Types 1 and 2; Type 5) or added (Types $3 \mathrm{a}$ and $3 \mathrm{~b}$ ).

strains differ with respect to allelic variants that control nerve cell numbers, we compared in preliminary experiments retinal cell densities of C57BL/6J (purchased from The Jackson Laboratory) and $\mathrm{C} 57 \mathrm{BL} / 6 \mathrm{NCrl}$ (purchased from Charles River Laboratories). Retinal whole mounts were triple stained for PNA to reveal cone pedicles, calbindin to label horizontal cells, and ChAT to stain OFF and ON cholinergic amacrine cells. It had been shown that the densities of these cells vary in different mouse strains (Raven et al., 2005; Reese et al., 2005; Keeley et al., 2007; Whitney et al., 2008). Supplemental Figure 1 (available at www. jneurosci.org as supplemental material) shows labeled cone pedicles, horizontal cells, and OFF and ON cholinergic amacrine cells in retinal whole mounts. The following densities (cells per square millimeter) were measured from eight fields (four peripheral and four central): C57BL/6J mice, cone pedicles, 13,435 \pm 1961 ; horizontal cells, $1120 \pm 133$; OFF cholinergic amacrine cells, $1259 \pm 261$; ON cholinergic amacrine cells, $1084 \pm 104$; C57BL/6NCrl mice, cone pedicles, $12,760 \pm 818$; horizontal cells, $1128 \pm 78$; OFF cholinergic amacrine cells, $1220 \pm 170 ;$ ON cholinergic cells, $1071 \pm 110$.

The densities of the four cell types did not differ

significantly between the two substrains and are in agreement with published data of C57BL/6 mice (Jeon et al., 1998; Strettoi and Pignatelli, 2000; Whitney et al., 2008). On this basis, we assume that data gained from either substrain of C57BL/6 mice are interchangeable.

\section{Results}

Cone contacts and retinal mosaic of Type 7 bipolar cells

In transgenic mice (Gus-GFP), which express GFP under the control of the gustducin promoter (Huang et al., 2003; Lin and Masland, 2005), Type 7 bipolar cells and their axons terminating in sublamina 4 of the IPL are prominently labeled (Fig. $2 A$ ). Less intense GFP expression is also found in RB cells and their axon terminals in sublamina 5, close to the ganglion cell layer. Across the retinal surface of Gus-GFP mice, staining of Type 7 bipolar cells is patchy; in some areas, all cells express GFP, whereas in other areas only individual cells are labeled. Figure $2 B$ shows a well isolated Type 7 cell in a horizontal view with the focus on the dendrites. The dendrites branch into many small terminals, which are the sites of contact with cone pedicles. With the plane of focus in sublamina 4 , the axon terminal of this cell becomes apparent (Fig. $2 C$ ), and, in sublamina $5, \mathrm{RB}$ axon terminals are found (Fig. 2D). Focusing through a retinal whole mount thus reveals the whole Type 7 cell, dendrites, cell body, and axon terminal. The cone pedicles were labeled in the same whole mounts with antibodies against glypho, alternatively for PNA, or by the staining of GluR5 in bipolar cell dendritic tips (Haverkamp et al., 2005).

The convergence of cones onto Type 7 bipolar cells was measured in well isolated Type 7 dendritic trees (Fig. 3A-D). The cell in Figure $3 A$ (same cell as in Fig. 2B,C) was in contact with seven cone pedicles, and that in Figure $3 C$ contacted nine cones. The histogram in Figure $3 E$ shows, measured for a sample of 94 cells, the frequency of cone contacts, which ranged from 5 to 12 with a mean \pm SD of $8.4 \pm 1.4(n=94)$.

Cone pedicles close to the center of a bipolar cell dendritic field receive more dendritic terminals, and cone pedicles innervated by distal dendrites receive fewer contacts (Fig. $3 A, B$ ) (supplemental Fig. $2 A$, available at www.jneurosci.org as supplemen- 

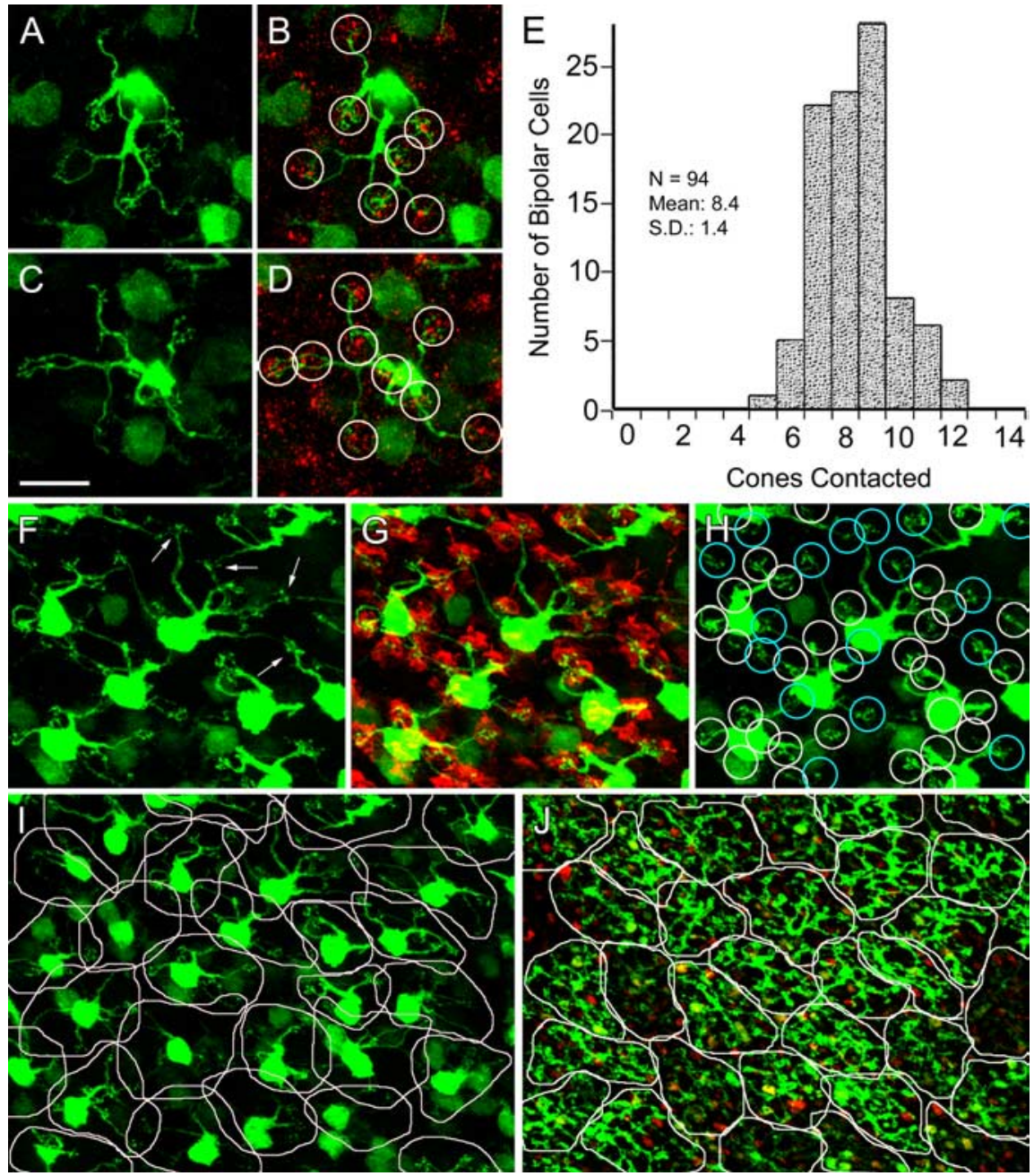

Figure 3. Cone contacts of Type 7 bipolar cells. A, C, Dendritic trees of two Type 7 bipolar cells. B, D, Their cone contacts (red label, GluR5 marking cone pedicles). $\boldsymbol{E}$, Frequency histogram of the number of cone contacts of individual Type 7 cells. $\boldsymbol{F}$, Group of neighboring Type 7 cells. $\mathbf{G}$, Same field as in $\boldsymbol{F}$ (red label, glypho-stained cone pedicles). $\boldsymbol{H}$, Blue circles mark cones contacted by two bipolar cells, and white circles mark cones contacted by one bipolar cell. $I$, Dendritic fields of Type 7 bipolar cells outlined by white lines. $J$, Axon terminals of the bipolar cells in $I$, outlined by the white lines. Scale bar: $\boldsymbol{A}-\boldsymbol{D}, 12.5 \mu \mathrm{m}$; $\boldsymbol{F}-\boldsymbol{H}, 15 \mu \mathrm{m} ; \boldsymbol{I}, \boldsymbol{J}, 20 \mu \mathrm{m}$.

tal material). This was quantified by measuring the area of contact between dendritic terminals and cone pedicles in relation to distance from the center (supplemental Fig. $2 \mathrm{~B}$, available at www.jneurosci.org as supplemental material). The sizes of the contacts decreased for distal dendrites and dropped to $50 \%$ at $\sim 12.5 \mu \mathrm{m}$ eccentricity (supplemental Fig. $2 C$, available at www. jneurosci.org as supplemental material). Comparable results have been found by P. W. Keeley and B. E. Reese (personal communication). They counted the number of dendritic terminals per pedicle and found six in the center, which dropped to 3 at 12.5 $\mu \mathrm{m}$ eccentricity. Cone pedicles in the center of the bipolar cell dendritic field provide, therefore, a stronger input than peripheral ones, and the sensitivity profile of a bipolar cell will be bell shaped (Dacey et al., 2000). However, it has to be emphasized that the feedback from horizontal cells and the electrical coupling of neighboring cones both will also have major influences on the overall shape of the sensitivity profile (Hornstein et al., 2004).

The divergence of the cone signal, that is the number of Type 7 bipolar cells to which a given cone is connected, was studied in well stained patches, in which all Type 7 cells were labeled (Fig. $3 F-H)$. The dendritic trees of the cells were more or less isolated
(Fig. 3F), but, in some instances, peripheral dendrites of neighboring cells terminated at the same cone pedicle (Fig. $3 F$, arrows). As mentioned above, peripheral dendrites provide smaller contacts with cone pedicles, which might be compensated by such double innervation. Figure $3 G$ shows the cone pedicle in addition to the bipolar cells, and Figure $3 H$ presents an analysis of the cone contacts. White circles show cone pedicles contacted by dendrites of only one bipolar cell, and blue circles indicate pedicles that innervate two bipolar cells. The mean number of Type 7 bipolar cells a given cone connects, the divergence of the cone signal, is between 1 and 2. There is not much redundancy in this connectivity pattern; it just ensures that each and all cone pedicles in Figure $3 \mathrm{H}$ are contacted by at least one Type 7 bipolar cell without any "blind spots." Figure $3 I$ shows the cell bodies and dendritic territories of Type 7 cells in a larger area (which includes the cells analyzed in Fig. $3 F-H$ ). The dendritic fields (white outlines) do not show much overlap.

The same holds true for the axon terminals (Fig. 3J). By following the descending axons through the stack of optical sections, it was possible to delineate the individual axon terminals (Fig. 3J, white outlines). Neighboring axons do not overlap; they are strictly territorial.

We analyzed the density of Type 7 bipolar cells together with the cone density in nine fields $(141 \times 106 \mu \mathrm{m}$ wide $)$ and found, as shown in Table 1 , a mean \pm SD bipolar cell density of $2256 \pm 221 / \mathrm{mm}^{2}$ $(n=9)$ and a mean \pm SD cone density of $14,833 \pm 2602 / \mathrm{mm}^{2}(n=9)$. There were $6.6 \pm 1.2$ times (mean $\pm \mathrm{SD} ; n=9$ ) more cones than Type 7 bipolar cells, which means that Type 7 bipolar cells have to contact at least 6.6 cones to provide a coverage of 1 . As shown in Figure 3E, Type 7 bipolar cells contact a mean of 8.4 cones, and, therefore, the coverage is $8.4 / 6.6=1.3$.

In conclusion, dendritic trees and axon terminals of Type 7 cells tile the retina without much overlap; they are territorial. Type 7 bipolar cells contact on average 8.4 cones. All cones (leaving aside blue cones) are contacted by at least one Type 7 cell (coverage of 1.3). In the ventral retina of the mouse, most cones express both M- and S-opsin (Szél et al., 1992). When we mention "blue cones," we refer to the genuine blue cones that express only S-opsin and comprise $<5 \%$ of mouse cones (Haverkamp et al., 2005). We did not specifically label blue cone pedicles in the present study and did not address the question as to whether certain bipolar cell types contact or avoid blue cone pedicles.

Cone contacts and retinal distribution of Type 3 bipolar cells By the application of two immunocytochemical markers, antibodies against HCN4 channels and antibodies against PKARII $\beta$, Mataruga et al. (2007) could show that Type 3 bipolar cells can be subdivided in Type $3 \mathrm{a}$ and Type $3 \mathrm{~b}$. Type $3 \mathrm{a}$ and $3 \mathrm{~b}$ cells were 
originally considered to represent one morphological type because their axons terminate in a narrow stratum in sublamina 2 of the IPL (Fig. 1). Differences in their dendritic morphology and their axon terminals did not show up in the vertical view of Lucifer-yellow-injected cells on which the classification of Ghosh et al. (2004) was based.

We applied in the present study antibodies against HCN4 and PKARII $\beta$ to retinal whole mounts and analyzed the cone contacts and retinal distributions of Type $3 \mathrm{a}$ and Type $3 \mathrm{~b}$ bipolar cells (Fig. 4). Type 3 a cells have curly dendrites (Fig. $4 A$ ), and the dendritic terminals surround the cone pedicles like nests. Type $3 \mathrm{~b}$ cells have more crescent-shaped dendrites that approach the cone pedicles more directly (Fig. 4D). Close inspection of Figure $4, A$ and $B$, shows that all cone pedicles are in contact with bipolar cell dendritic terminals. However, both Type $3 \mathrm{a}$ and $3 \mathrm{~b}$ cells have dendritic terminals that are not associated with cone pedicles (Fig. $4 A, B$, arrows), and we interpret such terminals as contacts with rod spherules (Mataruga et al., 2007). We also measured the number of cones contacted by individual Type $3 \mathrm{a}$ (Fig. 4C) and Type $3 \mathrm{~b}$ cells (Fig. 4F), the convergence of the cone signal. It was found that Type $3 \mathrm{a}$ cells contacted a mean $\pm \mathrm{SD}$ of $7.6 \pm 2.2(n=89)$ cones, whereas Type $3 \mathrm{~b}$ contacted a mean \pm SD of $6.2 \pm 2(n=62)$ cones only. This is compensated by the higher density of Type $3 \mathrm{~b}$ cells. The density of Type 3 a cells (Table 1) was $1866 \pm 605 / \mathrm{mm}^{2}$ (mean $\pm \mathrm{SD} ; n=$ 16), and that of Type $3 \mathrm{~b}$ cells was $3254 \pm$ $536(n=11)$. There were $6.1 \pm 0.9$ times (mean $\pm \mathrm{SD} ; n=16$ ) more cones than Type 3 a bipolar cells and $4.0 \pm 0.4$ times (mean $\pm \mathrm{SD} ; n=11$ ) more cones than Type $3 \mathrm{~b}$ cells. The resulting coverage of Type $3 \mathrm{~b}$ cells was 7.6/6.1 $=1.25$, and that of Type $3 \mathrm{~b}$ cells was $6.2 / 4.0=1.55$. This shows that each and all cones (leaving aside blue cones) are contacted by at least one Type $3 \mathrm{a}$ and one Type $3 \mathrm{~b}$ cell.

The axon terminals of Type 3a cells (Fig. $4 B$ ) are thicker and more varicose than those of Type $3 \mathrm{~b}$ cells (Fig. $4 E$ ). The white outlines show the axonal territories. The axon terminals of Type 3a cells do not overlap their next neighbors (Fig. $4 B$ ), and the same holds true for the axon terminals of Type $3 \mathrm{~b}$ cells (Fig. $4 E$ ). However, it has to be emphasized that they both costratify in sublamina 2, and, therefore, axon terminals of Type $3 \mathrm{a}$ and $3 \mathrm{~b}$ cells must intermingle. This predicts that the territorial behavior of axon terminal has to be regulated by highly type-specific interactions and signals.

Bipolar cells immunostained for calsenilin and the neurokinin receptor $\mathrm{NK}_{3} \mathrm{R}$

A retinal whole mount that was triple immunostained for GluR5, calsenilin, and $\mathrm{NK}_{3} \mathrm{R}$ is shown in Figure 5, $A$ and $B$. GluR5 marks the cone pedicles, and calsenilin reveals the dendritic network of
Type 4 bipolar cells (Fig. 5A) (Haverkamp et al., 2008). Type 4 bipolar cells have more diffuse axon terminals within sublamina 1 and 2 of the IPL (Fig. 1). Unfortunately, in the whole mount, we were not able to separate the axon terminals because calsenilinlabeled additional cells in the ganglion cell layer and their dendrites overlapped with the Type 4 axon terminals. However, we could count the number of cones contacted by individual Type 4 cells and found a mean \pm SD convergence of $7.4 \pm 1.1(n=31)$. The mean \pm SD density of Type 4 cells was $3005 \pm 573 / \mathrm{mm}^{2}$ $(n=12)$, and the mean \pm SD cone density was $13,836 \pm 1530 /$ $\mathrm{mm}^{2}(n=12)$ (Table 1$)$. There were $4.6 \pm 0.7$ times (mean \pm SD; $n=12$ ) more cones than Type 4 cells, and the resulting coverage of Type 4 cells was $7.4 / 4.6=1.6$. This shows that each and all cones (leaving aside blue cones) are contacted by at least one Type 4 bipolar cell.

$\mathrm{NK}_{3} \mathrm{R}$ immunoreactivity in Figure $5 B$ is found in thick processes, and they also contact every cone pedicle. However, as has been described previously, two bipolar cell types, Type 1 and Type 2, are immunoreactive for $\mathrm{NK}_{3} \mathrm{R}$ (Haverkamp et al., 2003; Ghosh et al., 2004; Pignatelli and Strettoi, 2004). The axons of Type 1 and Type 2 cells terminate in sublaminas 1 and 2, and they 

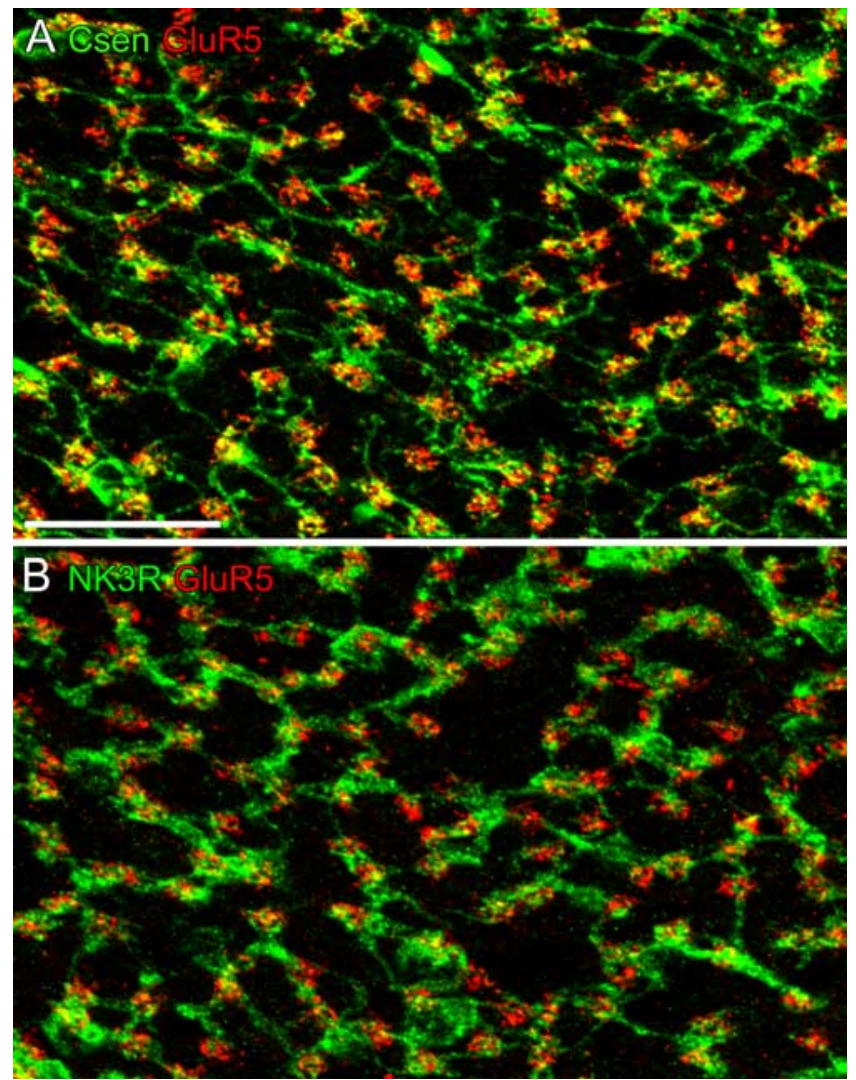

Figure 5. Dendritic trees of bipolar cells in a retinal whole mount that was triple labeled for calsenilin (Csen), $\mathrm{NK}_{3} \mathrm{R}$, and GluR5. $A$, Dendritic trees of Type 4 bipolar cells immunolabeled for calsenilin (green), cone pedicles are marked by GluR5 (red). $\boldsymbol{B}$, Dendritic trees of Type 1 and Type 2 bipolar cells immunolabeled for $\mathrm{NK}_{3} \mathrm{R}$ (green), cone pedicles are marked by GluR5 (red). Scale bar, $25 \mu \mathrm{m}$

form a dense plexus in $\mathrm{NK}_{3} \mathrm{R}$-labeled retinal sections and cannot be separated. Apparently, the same holds true for the dendrites, and, consequently, the thick processes in Figure $5 B$ may not represent individual dendrites but several dendrites fused into a single bundle. The mean $\pm \mathrm{SD}$ density of $\mathrm{NK}_{3} \mathrm{R}$-immunoreactive bipolar cell bodies was $4556 \pm 1491 / \mathrm{mm}^{2}(n=11)$, and the mean \pm SD cone density was $11,185 \pm 3186 / \mathrm{mm}^{2}(n=11)$ (Table 1). This is nearly twice the bipolar cell density encountered so far, and the high density supports the conclusion that $\mathrm{NK}_{3} \mathrm{R}$ immunoreactivity is found in two bipolar cell types. In the following, selective markers will be presented that separate these two bipolar cell types.

\section{Bipolar cells immunoreactive for synaptotagmin 2}

Fox and Sanes (2007) have shown that the synaptic vesicleassociated protein synaptotagmin 2 (Syt2) is expressed in bipolar cells with axon terminals in sublamina $1 / 2$ of the IPL. They demonstrated that these bipolar cells are also recoverin positive, which is unique for Type 2 cells (Haverkamp et al., 2003). Figure $6 \mathrm{~A}$ shows a vertical section of a mouse retina double labeled for Syt2 and calretinin. Syt2 immunoreactivity was present in rod spherules of the OPL, in bipolar cell bodies in the INL, and in two distinct groups of bipolar cell axon terminals in the IPL. The outer stratifying, brightly labeled axon terminals in sublamina $1 / 2$ are those of Type 2 bipolar cells as described by Fox and Sanes (2007). The inner, less intensely stained terminals in sublamina $3 / 4 / 5$ we classify as the axon terminals of Type 6 bipolar cells. When compared with the schematic drawing of the Type 6 cell in
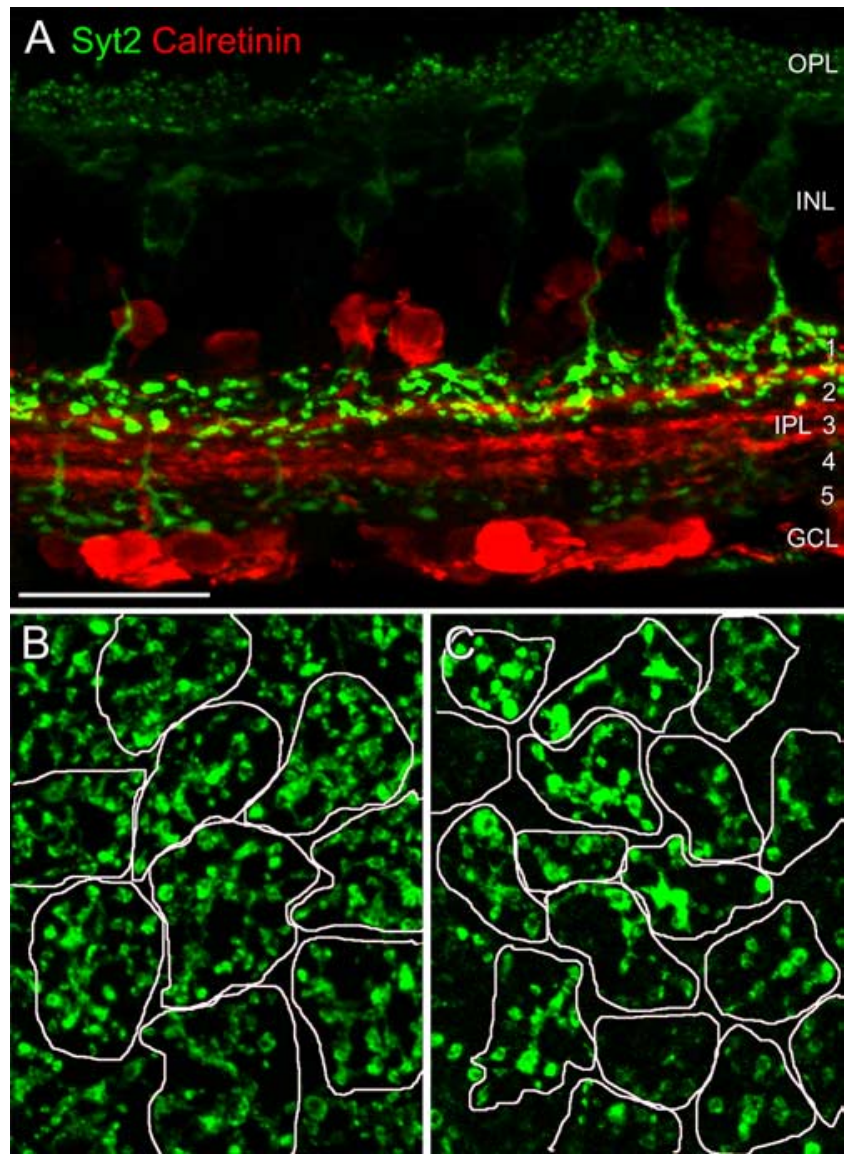

Figure 6. Syt2 immunostaining of Type 2 and Type 6 bipolar cells. $A$, Vertical section, double labeled for Syt2 (green) and calretinin (red). Axon terminals of Type 2 cells (in sublamina 1 and 2) are strongly labeled, and those of Type 6 cells (in sublamina 3-5) are weakly labeled. B, Axon terminals of Type 2 cells immunostained in a retinal whole mount for Syt2. C, Axon terminals of Type 6 cells. Scale bar, $25 \mu \mathrm{m}$.

Figure 1, the Syt2-labeled axon terminals follow the general description of Type 6 , but they are more varicose and most of their branches are found in sublamina 4/5. Type 7 bipolar cells and rod bipolar cell axons (Figs. 1,2) terminate also in sublamina 4/5 of the IPL, and, therefore, one has to exclude that Syt2 is expressed in these cells. We double labeled a section of the retina of the Gus-GFP mouse for GFP (Fig. 7B) and Syt2 (Fig. 7A). Syt2labeled axon terminals in sublamina $4 / 5$ intermingle with GFPlabeled Type 7 and RB axon terminals (Fig. 7C), but they are not double labeled. A confusion of Syt2-labeled axon terminals with Type 8 or Type 9 cell axons is not possible, because Type 8 cells have much wider axon terminals and Type 9 cells are much more sparsely distributed.

It was also possible to study Syt2-immunostained Type 2 and Type 6 axon terminals in retinal whole mounts. With the focus plane in sublamina $1 / 2$, the axon terminals of Type 2 (Fig. 6B) and in sublamina $4 / 5$ the axon terminals of Type 6 (Fig. $6 C$ ) became apparent. The white outlines define the area occupied by individual axon terminals, and, as described above for other types of bipolar cells, they are territorial and do not overlap with neighboring axon terminals. From the density of their axon terminals, we could estimate the mean \pm SD density of Type 6 bipolar cells (Table 1) as $3379 \pm 372 / \mathrm{mm}^{2}(n=8)$ at a mean \pm SD cone density of $12,916 \pm 1006 / \mathrm{mm}^{2}(n=8)$. The resulting cone to bipolar cell ratio of $3.9 \pm 0.5$ (mean $\pm \mathrm{SD} ; n=9$ ) predicts that Type 6 bipolar cells have to contact at least four cones (conver- 
gence) to provide a coverage of 1 . Unfortunately, only the axon terminals of Type 6 cells expressed Syt2; the dendrites were not labeled and their cone contacts could not be studied.

\section{Type 2 bipolar cells express GFP in the} Clm12 mouse retina

The Clm12 mouse is one of the transgenic mouse lines that express Clomeleon under the control of the thy-1 promoter. Because of the known variegation of this promoter, different retinal neurons express Clomeleon in the different mouse lines (Berglund et al., 2006). A retinal section of the Clm12 mouse line, immunostained for GFP, is shown in Figure 7E. Many ganglion and amacrine cells, as well as a sparse population of bipolar cells, are labeled. The section was also immunostained for Syt 2 (Fig. $7 D$ ), which labels Type 2 cells. Type 6 axon terminals are not visible in Figure $7 D$; they are too faintly stained. The superposition of the two figures in Figure $7 F$ shows that all GFP-immunoreactive bipolar cells also express Syt 2 and are, therefore, Type 2 cells. However, the dendrites of the GFPlabeled cells (Fig. 7E) are not obscured by rod spherules, and, therefore, the dendritic branching pattern of Type 2 cells could be studied in $\mathrm{Clm} 12$ mice.

Figure $8 \mathrm{~A}$ shows the dendritic network of Type 2 cells labeled for GFP in a whole mount of the Clm12 mouse retina. The cone pedicles were stained for PNA. Every single cone pedicle is in contact with a dendrite of a Type 2 cell. Some of the cells were well isolated and the convergence could be studied (Fig. 8C). Type 2 cells (Fig. $8 B$ ) contacted between three and eight cones (mean $\pm \mathrm{SD}, 5.6 \pm 1.2 ; n=66$ ). The outlines of the dendritic fields in Figure 8, $C$ and $D$, show that there is not much overlap between dendritic fields of neighboring Type 2 cells. This is also supported by the density measurements (Table $1)$. The mean \pm SD density of Type 2 cells was $3212 \pm 543 / \mathrm{mm}^{2}$ $(n=11)$, and the mean \pm SD density of cones sampled from the same retinal positions was $11,806 \pm 1371 / \mathrm{mm}^{2}(n=11)$. The cone to bipolar ratio was $3.8 \pm 0.7$ (mean $\pm \mathrm{SD} ; n=11$ ), and the coverage was $5.6 / 3.8=1.5$. Comparable with the other bipolar cells analyzed above, each and all cones (leaving aside blue cones) are contacted by one or two Type 2 bipolar cells.

Identification of Type $\mathbf{1}$ bipolar cells in Clm 1 transgenic mice In the retina of Clm1 transgenic mice, the blue cone bipolar cells (Type 9) were prominently labeled, and their selective contacts with blue cones and retinal distribution could be studied (Haverkamp et al., 2005). In addition to blue cone bipolar cells, additional bipolar cells were more weakly labeled, their labeling was patchy across the retina, and they comprised several morphological types (Duebel et al., 2006). Figure 9 shows a retinal whole mount of a Clm1 transgenic mouse that was triple labeled for $\mathrm{Clm}, \mathrm{NK}_{3} \mathrm{R}$, and Syt2. Type 1 and Type 2 bipolar cells together are immunoreactive for $\mathrm{NK}_{3} \mathrm{R}$ (Fig. 9A), whereas only Type 2 cells are immunolabeled for Syt2 (Fig. 9B). The superposition of $\mathrm{NK}_{3} \mathrm{R}$ and Syt 2 labeling (Fig. 9C), therefore, shows Type 2 cells double labeled and Type 1 cells single labeled for $\mathrm{NK}_{3} \mathrm{R}$. Figure $9 D$ shows the $\mathrm{NK}_{3} \mathrm{R}$ labeling and the bipolar cells expressing Clm. Most Clm-labeled bipolar cells within that field are also immunoreactive for $\mathrm{NK}_{3} \mathrm{R}$; hence, they are either Type 1 or Type 2 cells. Figure $9 E$ shows for the same field Clm expression and Syt2 labeling, and none of the Clm-labeled cell bodies express Syt2, which shows that they must represent Type 1 cells. Figure $9 F$ finally is a collapsed stack of the Clm-labeled bipolar cells, and the dendritic fields of two Type 1 cells are delineated by the white outline.

To estimate the density of Type 1 cells, whole mounts were triple labeled for glypho, which labels cones, for $\mathrm{NK}_{3} \mathrm{R}$ that labels Type 1 and Type 2 cells, and for Syt 2 that labels only Type 2 cells (data not shown). By subtracting the density of Syt2-labeled cells from the density of $\mathrm{NK}_{3} \mathrm{R}$-labeled cells the density of Type 1 cells was calculated. Alternatively, the bipolar cells were counted that expressed only $\mathrm{NK}_{3} \mathrm{R}$ but not Syt2. From these counts, a mean \pm SD density of Type 1 cells of $2233 \pm 399 / \mathrm{mm}^{2}(n=10)$ and a mean \pm SD density of cones of 11,840 $\pm 1315 / \mathrm{mm}^{2}(n=$ 10) were found (Table 1). There were $5.4 \pm 0.9$ times (mean \pm 

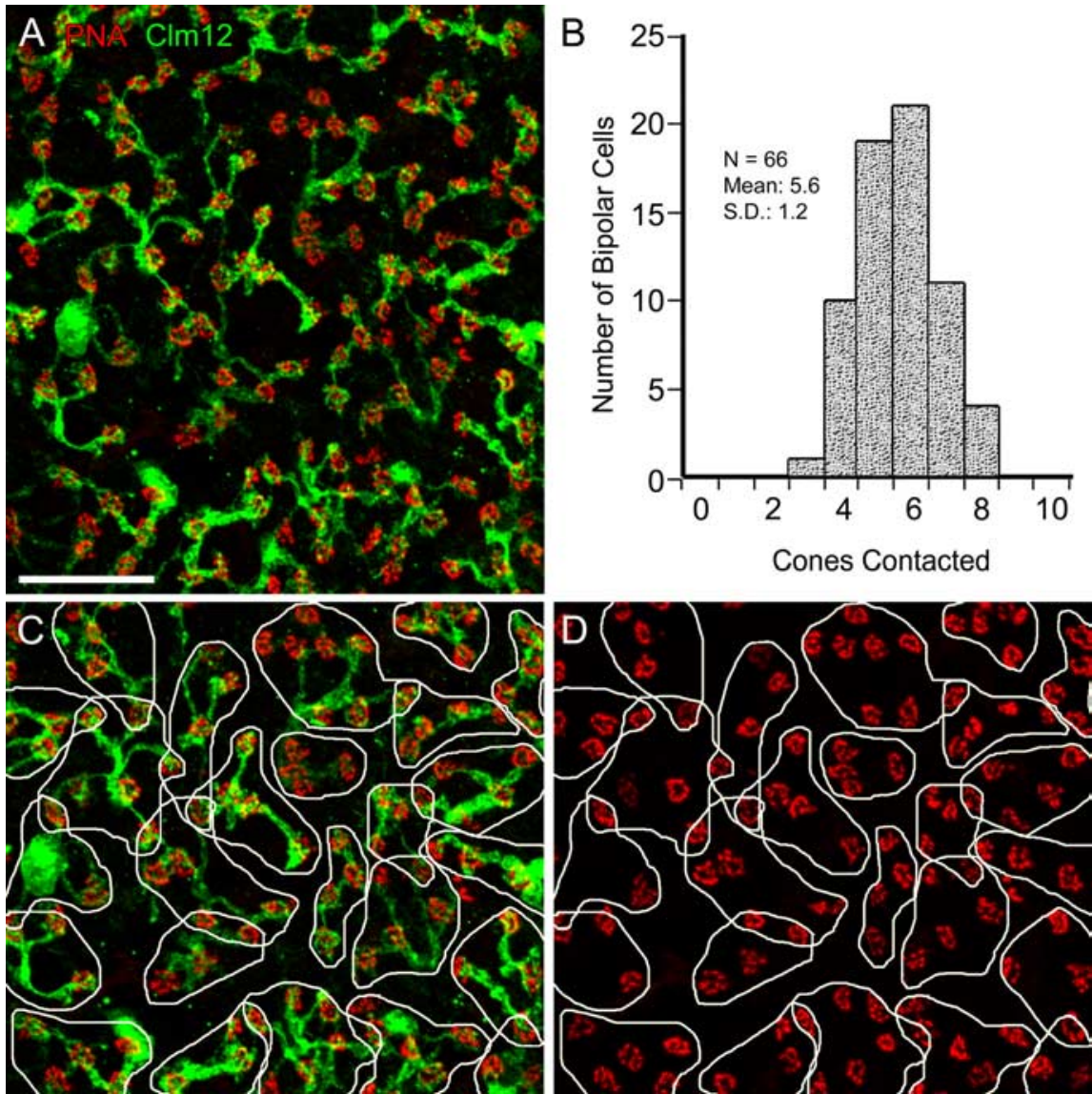

Figure 8. Dendritic network and cone contacts of Type 2 bipolar cells. $A$, Dendritic network of Type 2 bipolar cells in the Clm12 mouse (green) and cone pedicles (PNA labeled, red). $\boldsymbol{B}$, Frequency histogram of the number of cone contacts of Type 2 bipolar cells. C, Dendritic trees of the Type 2 bipolar cells in $\boldsymbol{A}$. D, Overlap of the dendritic trees in C. Scale bar: $\boldsymbol{A}, 25 \mu \mathrm{m} ; \boldsymbol{C}, \boldsymbol{D}, 22 \mu \mathrm{m}$.

SD; $n=10$ ) more cones than Type 1 bipolar cells. Clm1-labeled Type 1 bipolar cells contacted a mean \pm SD number of $8 \pm 1$ cones $(n=15)$, and, therefore, the coverage is $8 / 5.4=1.48$. All cones (leaving aside blue cones) are contacted by one or two Type 1 bipolar cells.

\section{Identification of Type 5 bipolar cells in $5-\mathrm{HT}_{3} \mathrm{R}-\mathrm{EGFP}$ transgenic mice}

In vertical sections through the retina of transgenic mice that express EGFP under the control of the $5-\mathrm{HT}_{3} \mathrm{R}$ promoter, exclusively bipolar cells were labeled (Fig. 10A). Double labeling the retina for calretinin and GFP (Fig. $10 \mathrm{~B}$ ) shows that the axons of GFP-labeled bipolar cells terminate in a narrow stratum representing sublamina 3 of the IPL, which corresponds to Type 5 bipolar cells (Fig. 1) (Ghosh et al., 2004). We studied the EGFPexpressing Type 5 cells and the cones also in retinal whole mounts (Fig. 10C,D). We had no difficulties in measuring the densities of Type 5 bipolar cells together with the cone densities. We could follow the axons descending into the IPL, but the axon terminals formed such a dense, overlapping meshwork that we failed to delineate individual axon terminals. The same was true for the dendritic trees. They contacted usually more than five cone pedicles, but we could not reliably define individual dendritic trees because of the strong overlap of dendrites. The mean \pm SD density of Type 5 bipolar cells was $5001 \pm 631 / \mathrm{mm}^{2}(n=10)$ at a mean \pm SD cone density of $12,687 \pm 1755 / \mathrm{mm}^{2}(n=10)$.

As can be seen in Table 1, the density of Type 5 bipolar cells is approximately twice that of other bipolar cells. We also listed at the bottom of Table $1 \quad \mathrm{NK}_{3} \mathrm{R}$ immunostained cells and Type 3 cells, which both comprise two types, for comparison with the Type 5 cells. Their densities and cone to bipolar cell ratios are closely similar, and the numbers predict that $5-\mathrm{HT}_{3} \mathrm{R}-$ EGFP (Type 5) cells actually are two types, Type $5 \mathrm{a}$ and Type 5b. This is supported by the dense network of their dendrites and axon terminals, which is probably the result of the superposition of two independent dendritic and axonal territories. In the rat retina, a subdivision of rat Type 5 bipolar cells by the application of antibodies against the different HCN channels HCN1, HCN2, and $\mathrm{HCN} 4$ has been described previously (Fyk-Kolodziej and Pourcho, 2007). However, application of the same antibodies to the mouse retina did not distinguish the Type $5 \mathrm{a}$ and $5 \mathrm{~b}$ cells postulated here (F. Müller, unpublished observations). Other markers that separate mouse Type $5 \mathrm{a}$ and $5 \mathrm{~b}$ cells will hopefully be found in the future.

\section{Discussion}

Is the catalog of mouse bipolar cells complete?

Five putative OFF cone bipolar cells were analyzed in the present study by selective markers (Fig. 11). Type 1 bipolar cells were found to be immunoreactive for $\mathrm{NK}_{3} \mathrm{R}$, and they could also be identified in Clm 1 transgenic mice. Type 2 bipolar cells expressed $\mathrm{NK}_{3} \mathrm{R}$ and Syt 2 immunoreactivity (Fox and Sanes, 2007). Type $3 a$ and Type $3 \mathrm{~b}$ cells were immunostained for HCN4 and PKARII $\beta$, respectively (Mataruga et al., 2007), and Type 4 cells expressed calsenilin (Haverkamp et al., 2008). In the case of ON cone bipolar cells, markers for four types were described. Type 5 bipolar cells were labeled in the $5-\mathrm{HT}_{3} \mathrm{R}-\mathrm{EGFP}$ mouse, but they represent two types (Fig. 11, named 5a and 5b). Type 6 bipolar cells were partially identified because their axons stratifying in sublamina 4/5 express Syt2. Type 7 bipolar cells were labeled in the Gus-GFP mouse (Huang et al., 2003). Type 9, the blue cone bipolar cell, has been identified in Clm1 mice (Haverkamp et al., 2005). Rod bipolar cells have been immunostained for PKC $\alpha$ (Negishi et al., 1988; Greferath et al., 1990). This list suggests that, with the exception of Type 8 bipolar cells, selective markers, which stain the whole population, are available for all bipolar cell types of the mouse retina. We would argue that this catalog of 11 cone bipolar and one rod bipolar types is complete for the following reason. The sum of the bipolar cell densities listed in Table 1 is $39,975 / \mathrm{mm}^{2}$, and the average \pm SD cone density is $12,867 \pm 1142(n=10)$. Jeon et al. (1998) have performed a quantitative study of the major cell populations of the C57BL/6NCrl mouse retina and described an average cone density of $12,400 / \mathrm{mm}^{2}$ and an average bipolar cell density of 41,221/ $\mathrm{mm}^{2}$. The difference between the bipolar cell densities of the present study and that of Jeon et al. (1998) is $1246 / \mathrm{mm}^{2}$ at a cone density of $12,400 / \mathrm{mm}^{2}$. This allows, postulating a coverage of 1 , the presence of an additional bipolar cell type that contacts a minimum of 10 cones. Type 8 bipolar cells have a wide dendritic field and a wide axon terminal (Ghosh et al., 2004) and thus may 

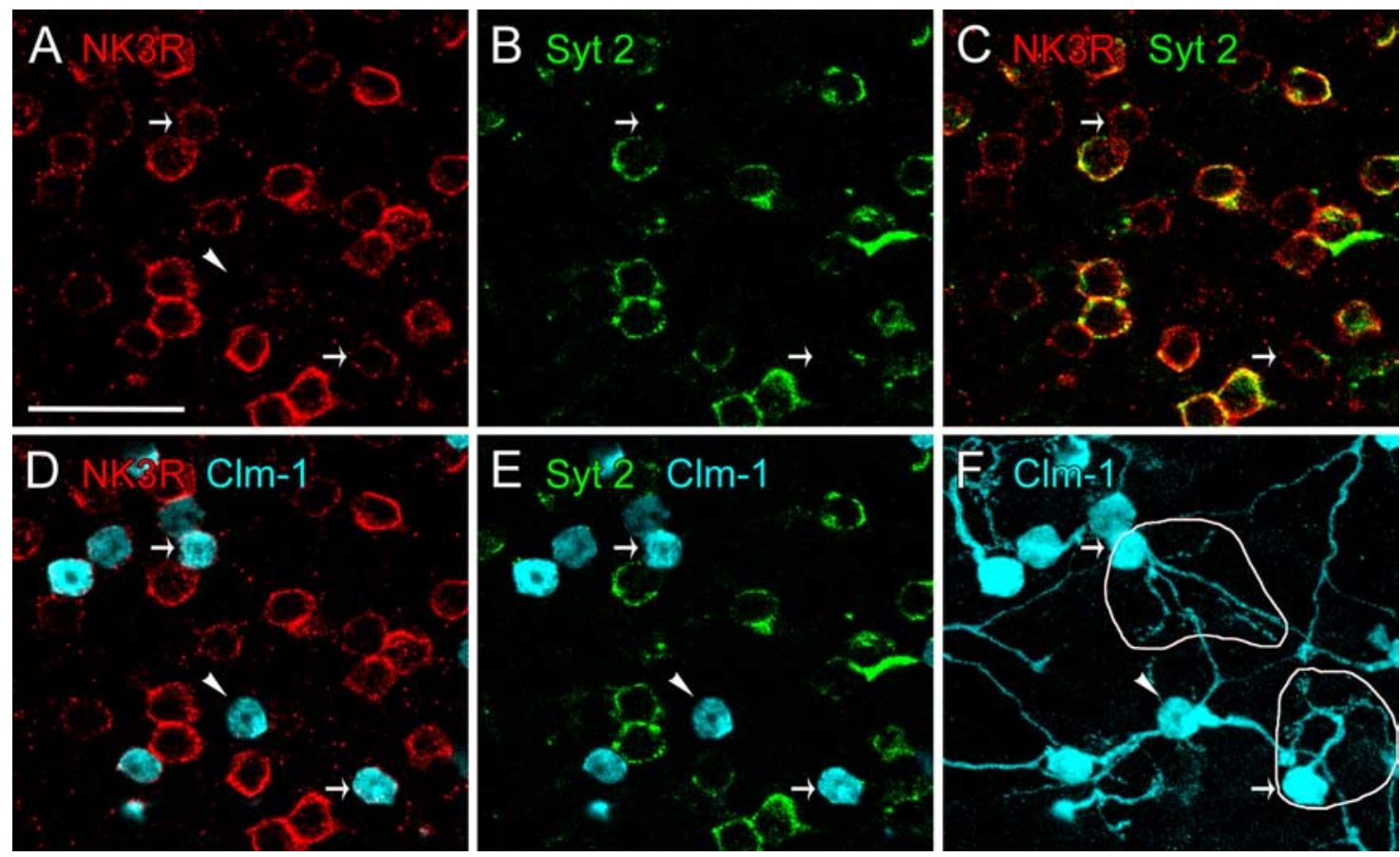

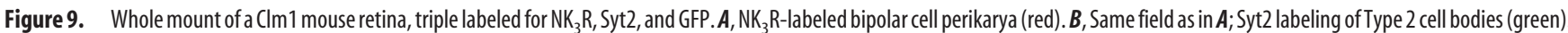
C, Superposition of $\boldsymbol{A}$ and $\boldsymbol{B}$ shows that Type 2 cells are double labeled for NK $\mathrm{NK}_{3}$ and Syt2. Bipolar cells expressing only NK $R$ represent Type 1 cells. $\boldsymbol{D}$, Same field as in $\boldsymbol{A}$ double labeled for NK ${ }_{3} R$ (red) and $\mathrm{CIm}$ (GFP, blue). With one exception (arrowhead), all GFP-labeled, blue cell bodies express also NK $\mathrm{R}$ (red). $\boldsymbol{E}$, Same field as in $\boldsymbol{A}$ double labeled for Syt2 (green) and (Im (GFP, blue). All GFP-labeled, blue cell bodies do not express Syt2 (green). $\boldsymbol{F}$, Same field as in $\boldsymbol{A}$, showing the dendritic fields of the Clm (GFP, blue)-labeled bipolar cells. The two bipolar cells marked by the arrows are not immunoreactive for Syt2 in $\boldsymbol{B}$ and $\boldsymbol{E}$ but are immunoreactive for $\mathrm{NK}_{3} \mathrm{R}$ in $\boldsymbol{A}$ and $\boldsymbol{D}$ and thus represent Type 1 bipolar cells. Their dendritic fields are outlined. Scale bar, $25 \mu \mathrm{m}$.

represent this type. This analysis suggests that the catalog of 11 cone bipolar cells and one rod bipolar cell is complete, and all major bipolar cell types of the mouse retina appear to have been discovered.

\section{Convergence and divergence of the cone signals}

The number of cone pedicles contacted by individual bipolar cells varied from an average of 5.6 for Type 2 cells to an average of 8.4 for Type 7 cells. Midget bipolar cells, which contact a single cone in the primate retina (Polyak, 1941), have not been observed in the mouse retina. The divergence of the cone signal (coverage) varied between 1 and 2 and did not differ significantly between the bipolar cell types. However, the quantitative analysis of the present study has shown that each and all cones are connected to at least one member of any given type of bipolar cell (leaving aside the blue cone pathway) (Haverkamp et al., 2005). Consequently, each cone pedicle is connected to a minimum of 10 different bipolar cells. They represent 10 separate channels that transfer the
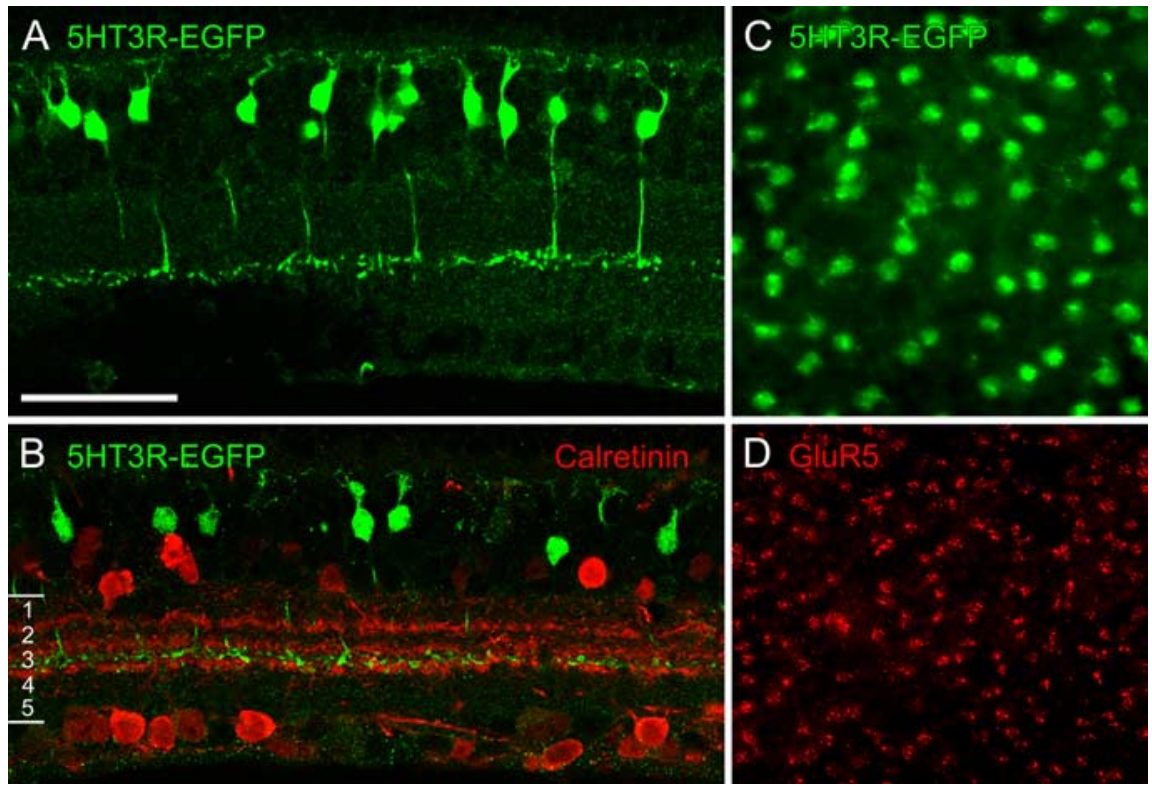

Figure 10. Type 5 bipolar cells are labeled in the $5-\mathrm{HT}_{3} \mathrm{R}-\mathrm{EGFP}$ mouse retina. $\boldsymbol{A}$, Vertical section through the retina of the $5-\mathrm{HT}_{3} \mathrm{R}-\mathrm{EGFP}$ mouse. $\boldsymbol{B}$, Vertical section double labeled for GFP (green) and calretinin (red). C, D, Same field of a whole mount of a $5-\mathrm{HT}_{3} \mathrm{R}$-EGFP retina. C, Focus on the cell bodies of GFP-labeled bipolar cells. $\boldsymbol{D}$, Focus on the cone pedicles marked by GluR5 immunostaining (red). Scale bar: $\boldsymbol{A}, \boldsymbol{B}, 25 \mu \mathrm{m} ; \boldsymbol{C}, \boldsymbol{D}, 32 \mu \mathrm{m}$. therefore, starts at the first synapse of the retina, the cone pedicle (Boycott and Wässle, 1999; Roska and Werblin, 2001).

\section{Dendritic field and axon territories of bipolar cells}

All cones within the dendritic tree of a given bipolar cell are contacted by this cell. Cone pedicles in the center of the dendritic field receive more dendritic terminals; cone pedicles innervated by distal dendrites receive fewer contacts (Fig. $3 A, B$ ) (supplemental Fig. 2, available at www.jneurosci.org as supplemental material). It is, therefore, to be expected that cones in the center contribute more weight to the light response than peripheral cones, and the sensitivity profile of bipolar cells is bell shaped 


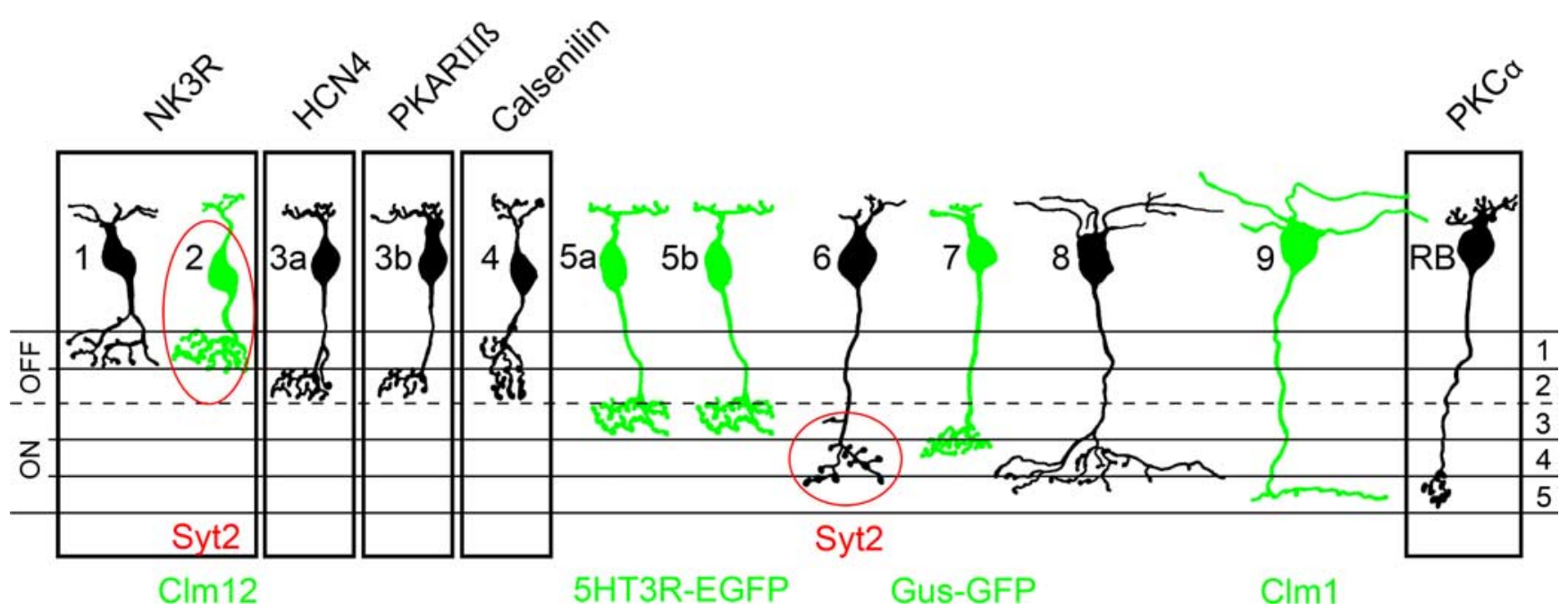

Figure 11. Summary diagram of the bipolar cell types as defined in the present study. A total of 11 cone bipolar cells and one rod bipolar cell could be distinguished by immunocytochemical staining (outlines) or by GFP/Clomeleon expression in transgenic mouse lines (green cells).

(Dacey et al., 2000). Distal dendrites of two neighboring bipolar cells often contact the same cone pedicle (Fig. $3 F-H$ ), which could compensate for the lower input weight to either bipolar cell. The summed sensitivity could thus be smooth giving every individual cone the same weight in the bipolar cell network (Borghuis et al., 2008).

The axon terminals of the different bipolar cell types showed a territorial behavior, and neighboring axon terminals of the same type did not overlap but filled the available space evenly with their varicosities. A comparable tiling has been described for rod bipolar axon terminals in the rabbit (Young and Vaney, 1991), for OFF midget bipolar cells in the primate (Milam et al., 1993; Wässle et al., 1994), and for calbindin-immunostained bipolar cells of the rabbit (Massey and Mills, 1996).

Such even distribution of axon terminals may also have the consequence that the output synapses of these bipolar cells are evenly distributed within their specific sublamina. An interesting question is how the precisely layered and territorial arrangement of axon terminals is formed during retinal development. Typespecific interactions have to be postulated because, as shown for the Type $3 \mathrm{a}$ and $3 \mathrm{~b}$ bipolar cell axon terminals (Fig. $4 B, E$ ), terminals of different types can overlap within the same sublamina. Yamagata and Sanes (2008) have presented evidence that, during embryonic development, proteins such as Dscam and Sidekick are involved in lamina-specific segregations of neuronal processes within the IPL.

Axon terminals of neurons that project from the lamina to the medulla in Drosophila show a type-specific segregation into different layers and a territorial columnar organization, which is comparable with the bipolar cell axons of the mouse retina (Millard et al., 2007). It has been shown by Millard et al. (2007) that elimination of Dscam 2 abolishes the territorial behavior of L1 axons. They proposed homophilic Dscam 2 interactions between neighboring axons followed by contact-dependent repulsion as the mechanism to make axon terminals territorial. Such contact dependent repulsion of axons has also been described recently for the axons of R8 photoreceptors in Drosophila (Tomasi et al., 2008). It is an attractive idea to postulate comparable mechanisms for the development of bipolar cell axon terminals in the mouse retina.

\section{Genetic markers of bipolar cells in the murine retina}

It has been shown that expression of specific genes is required for cone bipolar cell development. Irx5, a member of the Iroquois homeobox gene family, is expressed in developing bipolar cells and is localized to a specific subset of cone bipolar cells in the mature mouse retina (Cheng et al., 2005). In Irx5-deficient mice, defects were observed in Type 2 and Type 3 cone bipolar cells. The differentiation of these two bipolar cell types has been shown previously to require the homeodomain-CVC transcription factor Vsx1 (visual system homeobox 1) (Chow et al., 2004). More recently, novel genetic markers of murine bipolar cells have been found (Kim et al., 2008a,b). They have been attributed to ON cone, OFF cone, and rod bipolar cells by RNA in situ hybridization analysis. However, an attribution to specific types has not yet been possible. Badea and Nathans (2004) were able to identify different bipolar cell types of the mouse retina by a genetically directed alkaline phosphatase reporter. They performed a cluster analysis of the labeled cells, which accounted for parameters such as stratification and diameter of axon terminals. A total of eight clusters of bipolar cells was identified, and some of the clusters showed close correspondence to the classification applied in the present study. Cluster 4 appears to represent blue cone bipolar cells (Type 9), and cluster 8 is similar to Type 8 cells.

\section{Comparison of bipolar cell types among mammals}

There are at least nine morphological types of cone bipolar cells in the mammalian retina, which have been classified according to their branching pattern, the number of cones contacted, and the shape and stratification of their axons in the IPL (cat: Famiglietti, 1981; Kolb et al., 1981; McGuire et al., 1984; Pourcho and Goebel, 1987; Cohen and Sterling, 1990a,b; rabbit: Famiglietti, 1981; Mills and Massey, 1992; Jeon and Masland, 1995; McGillem and Dacheux, 2001; monkey: Boycott and Wässle, 1991; rat: Euler and Wässle, 1995; Euler et al., 1996; mouse: Ghosh et al., 2004; Pignatelli and Strettoi, 2004). During recent years, several immunocytochemical markers of cone bipolar cells have been identified. Unfortunately, some of these markers are expressed in different bipolar cell types among different species. Recoverin immunolabeling, for instance, is expressed in OFF midget bipolar cells of the macaque monkey retina (Milam et al., 1993; Wässle et al., 
1994), in OFF and ON bipolar cells of the rat retina (Euler and Wässle, 1995), and in OFF bipolar cells of the mouse retina (Haverkamp et al., 2003). In the marmoset monkey, CD15 is expressed in OFF midget and DB6 ON cone bipolar cells (Chan et al., 2001), in the rabbit, CD15 labels an ON cone bipolar cell (Brown and Masland, 1999), whereas in the mouse, CD15 is expressed in OFF cone bipolar cells (Jakobs et al., 2003; Ivanova et al., 2006). These examples show that a comparison of bipolar cell types between different species has to rely on multiple features, such as the expression of glutamate receptors (kainate or AMPA) (DeVries, 2000), the axonal stratification, and the cone convergence (midget or diffuse), and at present, a unifying classification scheme of mammalian bipolar cells is not yet possible.

\section{References}

Badea TC, Nathans J (2004) Quantitative analysis of neuronal morphologies in the mouse retina visualized by using a genetically directed reporter. J Comp Neurol 480:331-351.

Berglund K, Schleich W, Krieger P, Loo LS, Wang D, Cant NB, Feng G, Augustine GJ, Kuner T (2006) Imaging synaptic inhibition in transgenic mice expressing the chloride indicator, Clomeleon. Brain Cell Biol 35:207-228.

Borghuis BG, Ratliff CP, Smith RG, Sterling P, Balasubramanian V (2008) Design of a neuronal array. J Neurosci 28:3178-3189.

Boycott B, Wässle H (1999) Parallel processing in the mammalian retina. The Proctor Lecture. Invest Ophthalmol Vis Sci 40:1313-1327.

Boycott BB, Wässle H (1991) Morphological classification of bipolar cells in the macaque monkey retina. Eur J Neurosci 3:1069-1088.

Brandstätter JH, Koulen P, Wässle H (1997) Selective synaptic distribution of kainate receptor subunits in the two plexiform layers of the rat retina. J Neurosci 17:9298-9307.

Brown SP, Masland RH (1999) Costratification of a population of bipolar cells with the direction-selective circuitry of the rabbit retina. J Comp Neurol 408:97-106.

Chan TL, Martin PR, Clunas N, Grünert U (2001) Bipolar cell diversity in the primate retina: morphologic and immunocytochemical analysis of a new world monkey, the marmoset Callithrix jacchus. J Comp Neurol 437:219-239.

Chang B, Heckenlively JR, Bayley PR, Brecha NC, Davisson MT, Hawes NL, Hirano AA, Hurd RE, Ikeda A, Johnson BA, McCall MA, Morgans CW, Nusinowitz S, Peachey NS, Rice DS, Vessey KA, Gregg RG (2006) The nob2 mouse, a null mutation in Cacnalf: anatomical and functional abnormalities in the outer retina and their consequences on ganglion cell visual responses. Vis Neurosci 23:11-24.

Cheng CW, Chow RL, Lebel M, Sakuma R, Cheung HO, Thanabalasingham V, Zhang X, Bruneau BG, Birch DG, Hui CC, McInnes RR, Cheng SH (2005) The Iroquois homeobox gene, Irx5, is required for retinal cone bipolar cell development. Dev Biol 287:48-60.

Chow RL, Volgyi B, Szilard RK, Ng D, McKerlie C, Bloomfield SA, Birch DG, McInnes RR (2004) Control of late off-center cone bipolar cell differentiation and visual signaling by the homeobox gene Vsx1. Proc Natl Acad Sci U S A 101:1754-1759.

Cohen E, Sterling P (1990a) Demonstration of cell types among cone bipolar neurons of cat retina. Philos Trans R Soc Lond B Biol Sci 330:305-321.

Cohen E, Sterling P (1990b) Convergence and divergence of cones onto bipolar cells in the central area of the cat retina. Philos Trans R Soc Lond B Biol Sci 330:323-328.

Dacey D, Packer OS, Diller L, Brainard D, Peterson B, Lee B (2000) Center surround receptive field structure of cone bipolar cells in primate retina. Vision Res 40:1801-1811.

DeVries SH (2000) Bipolar cells use kainate and AMPA receptors to filter visual information into separate channels. Neuron 28:847-856.

Dhingra A, Sulaiman P, Xu Y, Fina ME, Veh RW, Vardi N (2008) Probing neurochemical structure and function of retinal ON bipolar cells with a transgenic mouse. J Comp Neurol 510:484-496.

Duebel J, Haverkamp S, Schleich W, Feng G, Augustine GJ, Kuner T, Euler T (2006) Two-photon imaging reveals somatodendritic chloride gradient in retinal ON-type bipolar cells expressing the biosensor clomeleon. Neuron 49:81-94.

Euler T, Wässle H (1995) Immunocytochemical identification of cone bipolar cells in the rat retina. J Comp Neurol 361:461-478.
Euler T, Schneider H, Wässle H (1996) Glutamate responses of bipolar cells in a slice preparation of the rat retina. J Neurosci 16:2934-2944.

Famiglietti EV Jr (1981) Functional architecture of cone bipolar cells in mammalian retina. Vision Res 21:1559-1563.

Feng G, Mellor RH, Bernstein M, Keller-Peck C, Nguyen QT, Wallace M, Nerbonne JM, Lichtman JW, Sanes JR (2000) Imaging neuronal subsets in transgenic mice expressing multiple spectral variants of GFP. Neuron 28:41-51.

Fox MA, Sanes JR (2007) Synaptotagmin I and II are present in distinct subsets of central synapses. J Comp Neurol 503:280-296.

Fyk-Kolodziej B, Pourcho RG (2007) Differential distribution of hyperpolarization-activated and cyclic nucleotide-gated channels in cone bipolar cells of the rat retina. J Comp Neurol 501:891-903.

Ghosh KK, Bujan S, Haverkamp S, Feigenspan A, Wässle H (2004) Types of bipolar cells in the mouse retina. J Comp Neurol 469 [Erratum (2004) 476:202-203]:70-82.

Greferath U, Grünert U, Wässle H (1990) Rod bipolar cells in the mammalian retina show protein kinase C-like immunoreactivity. J Comp Neurol 301:433-442.

Hack I, Peichl L, Brandstätter JH (1999) An alternative pathway for rod signals in the rodent retina: rod photoreceptors, cone bipolar cells, and the localization of glutamate receptors. Proc Natl Acad Sci U S A 96:14130-14135.

Hack I, Frech M, Dick O, Peichl L, Brandstätter JH (2001) Heterogeneous distribution of AMPA glutamate receptor subunits at the photoreceptor synapses of rodent retina. Eur J Neurosci 13:15-24.

Hartveit E (1997) Functional organization of cone bipolar cells in the rat retina. J Neurophysiol 77:1716-1730.

Haverkamp S, Grünert U, Wässle H (2001) Localization of kainate receptors at the cone pedicles of the primate retina. J Comp Neurol 436:471-486.

Haverkamp S, Ghosh KK, Hirano AA, Wässle H (2003) Immunocytochemical description of five bipolar cell types of the mouse retina. J Comp Neurol 455:463-476.

Haverkamp S, Wässle H, Duebel J, Kuner T, Augustine GJ, Feng G, Euler T (2005) The primordial, blue cone color system of the mouse retina. J Neurosci 25:5438-5445.

Haverkamp S, Specht D, Majumdar S, Zaidi NF, Brandstätter JH, Wasco W, Wässle H, Tom Dieck S (2008) Type 4 OFF cone bipolar cells of the mouse retina express calsenilin and contact cones as well as rods. J Comp Neurol 507:1087-1101.

Haverkamp S, Inta D, Monyer H, Wässle H (2009) Characterization of green fluorescent protein expressing retinal neurons in four transgenic mouse lines. Neuroscience, in press.

Hornstein EP, Verweij J, Schnapf JL (2004) Electrical coupling between red and green cones in primate retina. Nat Neurosci 7:745-750.

Huang L, Max M, Margolskee RF, Su H, Masland RH, Euler T (2003) G protein subunit $\mathrm{G} \gamma 13$ is coexpressed with $\mathrm{G} \alpha \mathrm{o}, \mathrm{G} \beta 3$, and $\mathrm{G} \beta 4$ in retinal ON bipolar cells. J Comp Neurol 455:1-10.

Ivanova E, Müller U, Wässle H (2006) Characterization of the glycinergic input to bipolar cells of the mouse retina. Eur J Neurosci 23:350-364.

Jakobs TC, Ben Y, Masland RH (2003) CD15 immunoreactive antacrine cells in the mouse retina. J Comp Neurol 465:361-371.

Jeon CJ, Masland RH (1995) A population of wide-field bipolar cells in the rabbit's retina. J Comp Neurol 360:403-412.

Jeon CJ, Strettoi E, Masland RH (1998) The major cell populations of the mouse retina. J Neurosci 18:8936-8946.

Keeley PW, Whitney IE, Raven MA, Reese BE (2007) Dendritic spread and functional coverage of starburst amacrine cells. J Comp Neurol 505:539-546.

Kim DS, Ross SE, Trimarchi JM, Aach J, Greenberg ME, Cepko CL (2008a) Identification of molecular markers of bipolar cells in the murine retina. J Comp Neurol 507:1795-1810.

Kim DS, Matsuda T, Cepko CL (2008b) A core paired-type and POU homeodomain-containing transcription factor program drives retinal bipolar cell gene expression. J Neurosci 28:7748-7764.

Kolb H, Nelson R (1995) The organization of photoreceptor to bipolar synapses in the outer plexiform layer. In: Neurobiology and clinical aspects of the outer retina (Djamgoz MBA, Archer SN, Vallerga S, eds), pp 273-296. London: Chapman and Hall.

Kolb H, Nelson R, Mariani A (1981) Amacrine cells, bipolar cells and ganglion cells of the cat retina: a Golgi study. Vision Res 21:1081-1114

Lin B, Masland RH (2005) Synaptic contacts between an identified type of 
ON cone bipolar cell and ganglion cells in the mouse retina. Eur J Neurosci 21:1257-1270.

Masland RH (2001) The fundamental plan of the retina. Nat Neurosci 4:877-886.

Massey SC, Mills SL (1996) A calbindin-immunoreactive cone bipolar cell type in the rabbit retina. J Comp Neurol 366:15-33.

Mataruga A, Kremmer E, Müller F (2007) Type 3a and Type 3b OFF cone bipolar cells provide for the alternative rod pathway in the mouse retina. J Comp Neurol 502:1123-1137.

McGillem GS, Dacheux RF (2001) Rabbit cone bipolar cells: correlation of their morphologies with whole-cell recordings. Vis Neurosci 18:675-685.

McGuire BA, Stevens JK, Sterling P (1984) Microcircuitry of bipolar cells in cat retina. J Neurosci 4:2920-2938.

Milam AH, Dacey DM, Dizhoor AM (1993) Recoverin immunoreactivity in mammalian cone bipolar cells. Vis Neurosci 10:1-12.

Millard SS, Flanagan JJ, Pappu KS, Wu W, Zipursky SL (2007) Dscam2 mediates axonal tiling in the Drosophila visual system. Nature 447:720-724.

Mills SL, Massey SC (1992) Morphology of bipolar cells labeled by DAPI in the rabbit retina. J Comp Neurol 321:133-149.

Negishi K, Kato S, Teranishi T (1988) Dopamine cells and rod bipolar cells contain protein kinase $\mathrm{C}$-like immunoreactivity in some vertebrate retinas. Neurosci Lett 94:247-252.

Nomura A, Shigemoto R, Nakamura Y, Okamoto N, Mizuno N, Nakanishi S (1994) Developmentally regulated postsynaptic localization of a metabotropic glutamate receptor in rat rod bipolar cells. Cell 77:361-369.

Pfeiffer-Guglielmi B, Fleckenstein B, Jung G, Hamprecht B (2003) Immunocytochemical localization of glycogen phosphorylase isozymes in rat nervous tissues by using isozyme-specific antibodies. J Neurochem 85:73-81.

Pignatelli V, Strettoi E (2004) Bipolar cells of the mouse retina: a gene gun, morphological study. J Comp Neurol 476:254-266.

Polyak SL (1941) The retina. Chicago: University of Chicago.

Pourcho RG, Goebel DJ (1987) A combined Golgi and autoradiograpphic study of ${ }^{3} \mathrm{H}$-glycine-accumulating cone bipolar cells in the cat retina. J Neurosci 7:1178-1188.

Raven MA, Stagg SB, Reese BE (2005) Regularity and packing of the horizontal cell mosaic in different strains of mice. Vis Neurosci 22:461-468.

Reese BE, Raven MA, Stagg SB (2005) Afferents and homotypic neighbors regulate horizontal cell morphology, connectivity, and retinal coverage. J Neurosci 25:2167-2175.

Roska B, Werblin F (2001) Vertical interactions across ten parallel, stacked representations in the mammalian retina. Nature 410:583-587.

Strettoi E, Pignatelli V (2000) Modifications of retinal neurons in a mouse model of retinitis pigmentosa. Proc Natl Acad Sci U S A 97:11020-11025.

Szél A, Röhlich P, Caffé AR, Juliusson B, Aguirre G, Van Veen T (1992) Unique topographic separation of two spectral classes of cones in the mouse retina. J Comp Neurol 325:327-342.

Tomasi T, Hakeda-Suzuki S, Ohler S, Schleiffer A, Suzuki T (2008) The transmembrane protein golden goal regulates R8 photoreceptor axonaxon and axon-target interactions. Neuron 57:691-704.

Wässle H (2004) Parallel processing in the mammalian retina. Nat Rev Neurosci 5:747-757.

Wässle H (2008) Decomposing a cone's output (parallel processing). In: The senses: a comprehensive reference (Basbaum AI, Kaneko A, Shepherd GM, Westheimer G, eds), pp 313-340. San Diego: Academic.

Wässle H, Grünert U, Martin PR, Boycott BB (1994) Immunocytochemical characterization and spatial distribution of midget bipolar cells in the macaque monkey retina. Vision Res 34:561-579.

Whitney IE, Keeley PW, Raven MA, Reese BE (2008) Spatial patterning of cholinergic amacrine cells in the mouse retina. J Comp Neurol 508:1-12.

Wong GT, Ruiz-Avila L, Margolskee RF (1999) Directing gene expression to gustducin-positive taste receptor cells. J Neurosci 19:5802-5809.

Yamagata M, Sanes JR (2008) Dscam and Sidekick proteins direct laminaspecific synaptic connections in vertebrate retina. Nature 451:465-469.

Young HM, Vaney DI (1991) Rod-signal interneurons in the rabbit retina. 1. Rod bipolar cells. J Comp Neurol 310:139-153. 